\title{
ON NEMATODE-DESTROYING FUNGI IN FINLAND. II
}

\author{
Arvi Salonen and Anna-Lirsa Ruokola \\ Department of Plant Pathology, University of Helsinki
}

Received April 29, 1968

In the first part of their study the present writers (Ruokola \& Salonen 1967) established the occurrence in Finland of two out of the eight known species of the Nematoctonusgenus described by Drechsler in 1941: $\mathcal{N}$. concurrens and $\mathcal{N}$. leiosporus. Regarding the occurrence and distribution of this genus of nematode-capturing Fungi imperfecti, which is provided with clamp-connections, the information available is very scanty. Many Nematoctonus-species have been described only by DrechsLer in the U.S.A. This may be due to the very scanty growth of these fungi which are hardly observable with the naked eye. Details on the material and methods of the present study have been presented earlier (Ruokola \& SALONEN 1967). The research material has been collected primarily from old Finnish timber-built bathhouses (»sauna»).

Nematoctonus robustus Jones, Trans.Brit.Mycol.Soc. 47:57-60, 1964.

After an incubation period of four weeks, small, white, pin-point size compact mycelium growth, composed chiefly of conidia, was found on shavings strewn on CMA plates. On the surface of the nutrient agar there appeared a scanty growth of hyaline, arachnoid hyphae, $1.0-1.5 \mu \varnothing$, which were provided with clamp-connections and were not easily observable. The conidiophores were either single, subspherical phialides or septate, irregular swellings of the hyphae, 10.6-16.0 $\mu$ in length, with the conidia attached to the numerous spikes and forming verticillate whorls. The swellings could be oblong with the conidia forming grape-like clusters. The hyaline, 1-celled, distally rounded conidia, 5.3$14.4 \times 2.1-4.0 \mu$, were either elongate-cylindrical, or curved into horse-shoe shape (Fig. 1); no signs of germinating were established.

Ta. Jaala 1; Loppi 2. - Sa. Joutseno 1; Mäntyharju 1.

The conidia reminded one of DrechsLeR's $\mathcal{N}$. campylosporus except that the conidiophores of this species are single, spike-like sterigmata (DrEchsLer 1954). On the other hand, the characteristics of the isolated strains corresponded in many respects with the facts given by Jones (1964) regarding $\mathcal{N}$. robustus, although the hyphae, as is common in the Nematoctonus-fungi, were thin and arachnoid. Nematode-capturing outgrowths found by JoNEs (1964) were not observed by the present authors. 


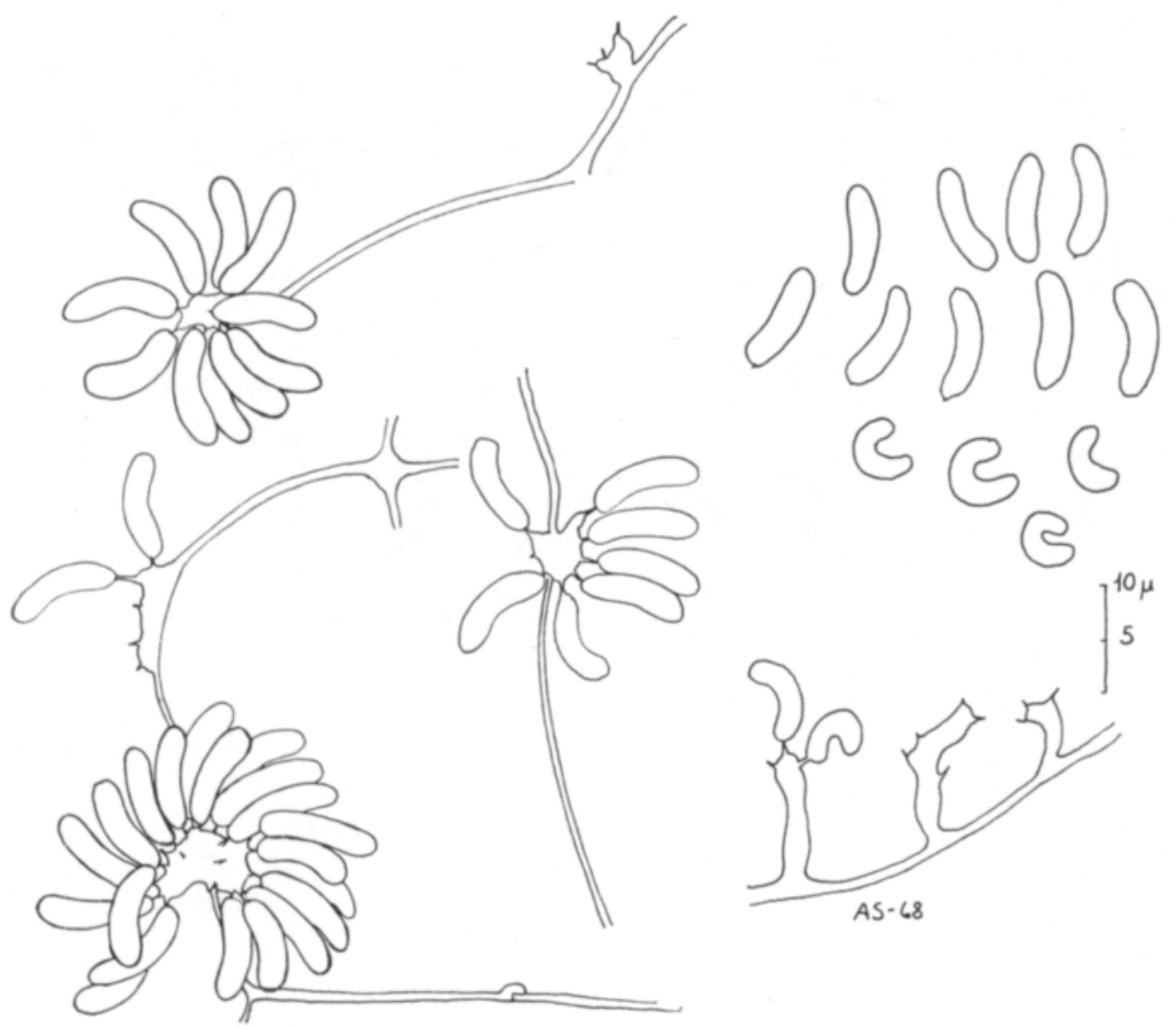

Fig. 1. Nematoctonus robustus Jones. Mycelium with clamp-connections and conidiophores with conidia. 60 days old CMA-culture.

N. robustus has been found in Ghana, Africa, in leaf mould composts already in 1958, although the description by Jones was published only in 1964. Further information on the occurrence of the fungus has not been found in the literature.

Nematoctonus lignicola sp. nov.

Mycelio delicato, albo humilique; hyphis hyalinis, $1.1-2.0 \mu . \varnothing$, in modum hymenomycetum septato-nodosis, parce ramosis; conidiophores simplices, dilatationis affectis, in sufflatibus hypharum, vel in brevibus ramis inordinatis constantibus, $10.6 \times 2.1$; sterigmatis conidiorum spinosis; conidiis incoloratis, elongatis, utrimque late rotundatis plerumque curvatis, $1-2$ septatis, $9.0-13.6 \times 2.8-$ $4.0 \mu$, singularibus aut botryoideis.

Habitat in ligno putrescenti, veterum aedificiorum balneariorum in paroechiis Loppi, Ta. 1 - Joutseno, Sa. 1; Jul. 1966.

It was established that the small, hardly discernible, white mycelium pointing to $\mathcal{N}$. robustus and found in the shavings of some specimens strewn on CMA plates belonged to an entirely new species of Nematoctonus. 


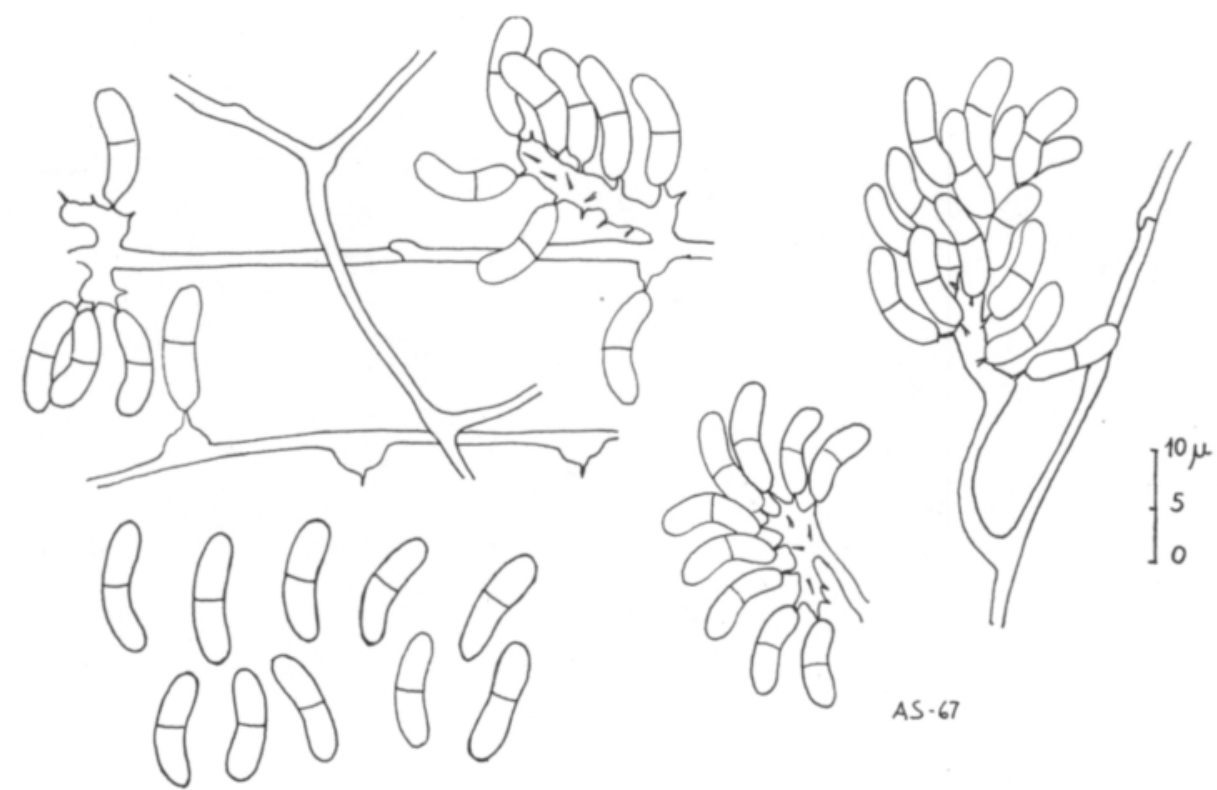

Fig. 2. Nematoctonus lignicola sp. nov. Mycelium with clamp-connections and conidiophores with conidia. 60 days old CMA-culture.

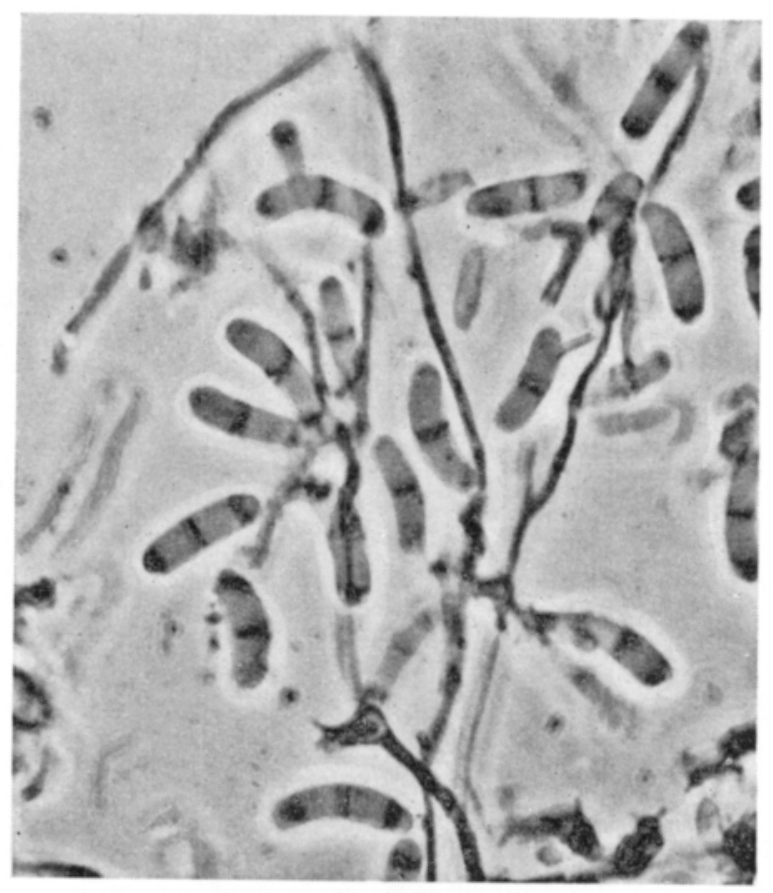

Fig. 3. Nematoctonus lignicola. 
The mycelium was delicate, white and low, the hyphae hyaline, $1.1-2.0 \mu \emptyset$, studded with clamp-connections, scantily branched; the conidiophores were single, subspherical with spike-like sterigmata, swellings of the hyphae or short irregular branches, $10.6 \times$ $2.1 \mu$, in which the conidia appeared singly or in grape-like clusters; the conidia were hyaline, elongate-cylindrical, curved, generally 2-celled, seldom 1- or 3-celled, 9.0$13.6 \times 2.8-4.0 \mu$ (Figs. 2 and 3).

Habitat on decaying wood, bath house ("sauna»); Loppi, Ta. 1-Joutseno, Sa. 1; July, 1966.

No nematodes were established on the plates and that may explain the absence of nematode-capturing organs in the mycelium. Morphologically the fungus greatly resembles $\mathcal{N}$. robustus (Fig. 1), although it clearly differs from the latter on account of its 2-celled conidia (Fig. 2).

Slides of this fungus are in the authors' collection at the Department of Plant Pathology, University of Helsinki.

\section{Su m mary}

A study carried out by the present authors (Ruokola \& SAlonen 1967) on the microflora of old timber-built bath-houses ("sauna») has revealed two species belonging to the Nematoctonus-genus in addition to the nematode-destroying fungi presented earlier: $\mathcal{N}$. robustus and a new species $\mathcal{N}$. lignicola.

\section{REFERENCES}

Drechsler, C. 1941. Some hyphomycetes parasitic on free-living terricolous nematodes. Phytopath. $31: 773-801$.

- - 1954. A nematode-capturing fungus with clamp-connections and curved conidia. J. Wash. Acad. Sci. $44: 82-85$.

Jones, F. R. 1964. Nematoctonus robustus sp. nov. Trans. Brit. Mycol. Soc. 47:57-60.

Ruokola, A-L. \& Salonen, A. 1967. On nematode-destroying fungi in Finland. J. scient. agr. soc. Finl. 39:119-130.

SELOST US

NEMATODEJA TUHOAVISTA SIENISTÄ SUOMESSA. II

Arvi Salonen ja Anna-Litsa Ruokola

Yliopiston kasvipatologian laitos, Helsinki

Vanhojen hirsisaunojen mikrofloraa koskevassa tutkimuksessamme (RUoKolA \& SALONEN 1967) on aikaisemmin esitettyjen, nematodeja tuhoavien sienien lisäksi löydetty kaksi Nematoctonus-sukuun kuuluvaa lajia: $\mathcal{N}$. robustus sekä uusi laji $\mathcal{N}$. lignicola. 